\title{
Healthy Living in Makassar's Family Based on Thier Faith
}

\author{
Muhammad Saleng ${ }^{1}$, Hermansyah ${ }^{2}$, Ardhanari Hendra Kusuma ${ }^{3}$, Bahruddin ${ }^{1}$, M.Natsir ${ }^{1}$, Abidin ${ }^{1}$, Agussalim $^{1 *}$ \\ ${ }^{1}$ Parepare Nursing School, Makassar Health Polytechnic, Jalan Laupe, Soreang, Parepare City, South Sulawesi Province, Indonesia. \\ ${ }^{2}$ Aceh Nursing School, Aceh Health Polytechnic, Jalan Soekarno-Hatta, Lagang, Darul Imarah, Banda Aceh City, Aceh Province, Indonesia. \\ ${ }^{3}$ Serui Nursing School, Jayapura Health Polytechnic, Jalan Hermanus Kayai, Kelurahan Anotaurei, Kepulauan Yapen Resident, Papua \\ Province,Indonesia
}

*Corresponding Author: Agussalim, Parepare Nursing School, Makassar Health Polytechnic, Jalan Laupe, Soreang, Parepare City, South Sulawesi Province, Indonesia.

\section{Received date: September 13, 2021: Accepted date: October 09 2021: Published date: January 04, 2022}

Citation: Md Saleng, Hermansyah, Ardhanari H Kusuma, Bahruddin, M.Natsir, Abidin, (2022) Fluctuating RT-PCR Ct Values- A Case Series Healthy Living in Makassar's Family Based on Thier Faith. J. Clin Case Rep and Stu 3(1); DOI: 10.31579/2690-8808/091

Copyright: (c) 2022 Agussalim. This is an open access article distributed under the Creative Commons Attribution License, which permits unrestricted use, distribution, and reproduction in any medium, provided the original work is properly cited.

\begin{abstract}
Various aspects of human life are organized in Muslim community, including health problems. Islam highly upholds the health in which many people are deceived from such health. One of the efforts that can be done to maintain the health given by god is to implement clean and Healthy Living Behavior in families, schools and others. This research was conducted at Mosque of Antang, Makassar. This research was conducted using Cross Sectional design. The sample used as many as 40 respondents; data analysis used is univariate and bivariate with chi-square test. The results of statistical tests of Hand Washing Orders and defecation obtained a value of $p$ Value of 0.000 , and Smoking Prohibition obtained a value of $\mathrm{p}$ Value of 0.001 , the test results showed that there is a relationship between Hand Washing Orders, defecation and Smoking Prohibition with Clean and Healthy Living Behavior, because the calculated value of $\mathrm{P}<\alpha=0.05$. Based on the research, it can be concluded that Clean and Healthy Living Behavior of Applied Mosque Antang is in the good category. Where they are washing Their Hands, Make Latrines and without Smoking because of the encouragement of faith in their hearts, fear and obedience to the command of God and the magnitude of their love for the Messenger. Therefore, it is expected through this research that the People of Indonesia to further increase faith and following to god and love and practice of the Messenger of God in daily life.

Keywords: hand washing orders; prohibition; smoking
\end{abstract}

\section{Background}

Health is one of the gifts given by God to all his followers that must be maintained and grateful. A man will not feel happiness if he does not have health even though he has a lot of wealth. Therefore we are required to maintain health before the health is lost. Healthy is a condition free from the problem of meeting the basic needs of the community or is a dynamic balance as a result of success that overcomes stressors. (Komang Ayu Henny Achajar, 2013).

Health Law No.23 of 1992 provides restrictions on health, namely the state of welfare of the body, soul and social that allows everyone to live productively socially and economically. This latest restriction is lifted from health restrictions according to the World Health Organization (WHO) (Arsita Eka Prasetyawati, 2011)

Islam is the one religion in the world. Various aspects of human life are organized within Islam, including health problems. Islam highly upholds the health in which many of the human beings are deceived from such health.

Clean and Healthy Living Behavior is the essence and human right to maintain its survival. This is in line with the world health organization constitution in 1948 agreed among others that obtaining the highest level of health is a fundamental right for everyone regardless of race, religion, politics and socioeconomic level. A high degree of health can be obtained if everyone has health-related behaviors (Anik Maryunani, 2013).

Clean and Healthy Living Behavior is one of the government's priority programs through Public Health Center (PHC) and becomes an external target in the implementation of health development, as mentioned in the Strategy Plan of the Ministry of Health in 2010-2014, (Ministry of Health, 2011) in Clean and Healthy Living Behavior (Anik Maryunani, 2013). Clean and Healthy Living Behavior objectives are not only limited to hygiene, but must be more comprehensive and broad, including changes in the physical environment, biological environment and socio-cultural environment of society so as to create a health-minded environment and changes in clean and healthy living behavior (Anik Maryunani, 2013).

Based on the results of the health profile of districts / cities in 2010 households are monitored $87.80 \%$ and there are $60.91 \%$ of households who implement a clean and healthy lifestyle, which means that the achievement of the program has not reached the target of Healthy Indonesia indicators namely $(65 \%)$ while in 2011 households were monitored $60.04 \%$ and there were $57.44 \%$ of households implementing a 
clean and healthy lifestyle, in 2012 households were monitored 61.80 and there were $54.85 \%$ of households implementing a clean and healthy lifestyle as for the highest achievement of Makassar city district (72.41\%) and the lowest in Maros district (22.97\%). While in 2013 households were monitored 64.20 and there were $53.41 \%$ of households implementing a clean and healthy lifestyle as for the highest achievements, namely Parepare city district $(81,71 \%)$ Bone district $(22.83 \%)$ and Makassar (72.89\%) (South Sulawesi Health Center, 2015). Households that implement a clean and healthy lifestyle that is successfully monitored in the village of Antang are divided by the working area of the public health center, namely in the Antang PHC of 3,376 monitored that implement a clean and healthy lifestyle as much as 3,208 (95.0\%), Antang of 5.5455 monitored who implemented a clean and healthy lifestyle as many as 4,824 (88.4\%), and in Tamangapa PHC of 7,023 monitored who implemented a clean and healthy lifestyle as many as 4,868 (69.3\%). (Makassar City Health Office, 2017).

Taklim (applied) ceremony is held every week on Thursday night after magrib prayer until isya at Nur Taqwa Antang Raya Mosque, Manggala District, Makassar City. Taklim Council was attended by the community and surrounding areas with a total of 40 people. In the initial interview conducted there were some of the taklim assembly members who had good clean and healthy living behaviors.

\section{Purpose of research}

The purpose of this study in general is to identify the relationship of

Islamic teachings on health with Clean and Healthy Living Behavior order by family members of the taklim council in Nur Taqwa Antang Raya Mosque

\begin{tabular}{|l|l|l|l|}
\hline № & Respondent's Age & Frequency & Percentage $\%$ \\
\hline 1 & $21-30$ years old & 6 & 31,6 \\
\hline 2 & $31-40$ years old & 10 & 22,6 \\
\hline 3 & $41-50$ years old & 2 & 10,5 \\
\hline 4 & $51-65$ years old & 1 & 5,3 \\
\hline & Total & 19 & 100 \\
\hline
\end{tabular}

Source : Primary Data, July 2017Based on the table above (table 5.1) seen the most characteristics of respondents who have the age of $31-40$ years as many as 10 people (22.6\%) and respondents who have the age of 21-30 years as many as 6 people (31.6\%), and respondents who have the age of 41 50 years as many as 2 people (10.5\%), and the least is the age of 51-65 years that is as much as 1 person $(5.3 \%)$.

Table 5.1: Characteristics of Respondents by age at Antang mosque 2017

\section{b. Gender}

\begin{tabular}{|l|l|l|l|}
\hline № & Gender & Frequency & Percentage \% \\
\hline 1 & Male & 19 & 100 \\
\hline 2 & Women & 0 & 0 \\
\hline & Total & 19 & 100 \\
\hline
\end{tabular}

Source: Primary Data, July 2017

Based on the table above (table 5.2) of the 19 respondents in this study, all were male with a total of 19 people (100\%).

Table 5.2: Respondent Characteristics by Gender at Antang mosque 2017

\section{c. Education}

\begin{tabular}{|l|l|l|l|}
\hline$№$ & Education & Frequency & Percentage \% \\
\hline 1 & No School & 1 & 5,3 \\
\hline 2 & Finished elementary school & 2 & 10,5 \\
\hline 3 & $\begin{array}{l}\text { Graduated from junior high } \\
\text { school }\end{array}$ & 1 & 5,3 \\
\hline 4 & Finished high school & 10 & 52,6 \\
\hline 5 & University & 5 & 26,3 \\
\hline & Total & 19 & 100 \\
\hline
\end{tabular}

Source: Primary Data, July 2017

This type of research is correlational research with cross sectional study approach. Correlational research examines the relationship between variables. The research was conducted at Antang Mosque conducted in Juk study is all members of the taklim council of Mosque Antang which amounts to 40 people. The sample technique used is purposive sampling. Purposive sampling is a sampling 列 / problem in the study). So that the sample

\section{Result of study}

This research was conducted in Antang mosque which was transferred by 19 respondents, using the Cross Sectional Study. Data retrieval was using questionnaire measuring instruments.After data retrieval, the next step is data processing using SPSS program. Further analysis of the results of the complete study will be presented in the form of a table covering the acteristics of respondents, analysis of univariate data against each

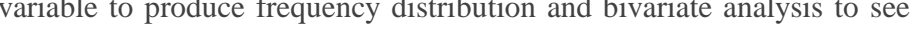
relationship between independent variables and dependent variables The results of the research obtained are as follows:

\section{Characteristics of respondents}

a. Age 
Based on the table above (table 5.3) of 19 respondents in this study, 1 person $(5.3 \%)$ No School, 2 people $(10.5 \%)$ finished elementary school,
1 person $(5.3 \%)$ junior high school graduation, 10 people $(52.6 \%)$ high school graduation, and 5 people $(26.3 \%)$ at university

\section{d. Work}

\begin{tabular}{|l|l|l|l|}
\hline № & Job & Frequency & Percentage \% \\
\hline 1 & Not Working & 2 & 10,5 \\
\hline 2 & Civil Servants & 2 & 10,5 \\
\hline 3 & Traders & 4 & 21,1 \\
\hline 4 & Private & 9 & 47,4 \\
\hline 5 & Etc & 2 & 10,5 \\
\hline & Total & 19 & 100 \\
\hline
\end{tabular}

Source: Primary Data, July 2017

Table 5.4: Characteristics of Respondents by occupation at Antang Mosque 2017

Based on the table above (table 5.4) it can be known that the distribution of the most types of work is private as many as 9 people $(47.4 \%)$, traders as many as 4 people $(21.1 \%)$, and respondents who do not work, civil servants and other jobs have the same number of 2 people $(10.5 \%)$.

\section{Characteristics of Variables Studied}

\begin{tabular}{|l|l|l|l|}
\hline$№$ & HandWashing Commands & Frequency & Percentage \% \\
\hline 1 & Do & 12 & 63,2 \\
\hline 2 & Not Doing & 7 & 36,8 \\
\hline & Total & 19 & 100 \\
\hline
\end{tabular}

Source : Primary Data, July 2017

Table 5.5: Frequency Distribution Based on Hand Washing Orders of Members of compound mosque, Antang 2017

Based on the table above (table 5.5) above it can be known that of the 19 respondents, who performed hand washing orders as many as 12 people $(63.2 \%)$ and who did not do as many as 7 people $(36.8 \%)$.

2) Defecation

Source: Primary Data, July 2017

\begin{tabular}{|l|l|l|l|}
\hline$№$ & Adab Buang Hajat & Frequency & Percentage \% \\
\hline 1 & Do & 13 & 68,4 \\
\hline 2 & Not Doing & 6 & 31,6 \\
\hline & Total & 19 & 100 \\
\hline
\end{tabular}

Table 5.6: Frequency Distribution based on defecation healthy style of member mosque Antang 2017

Based on the table above (table 5.6) above it can be known that out of 19 respondents, who performed defecation healthy style as many as 13 people $(68.4 \%)$ and who did not do as many as 6 people $(31.6 \%)$.

3) Smoking

\begin{tabular}{|l|l|l|l|}
\hline № & Smoking Ban & Frequency & Percentage \% \\
\hline 1 & Do & 14 & 73,7 \\
\hline 2 & Not Doing & 5 & 26,3 \\
\hline & Total & 19 & 100 \\
\hline
\end{tabular}

Source: Primary Data, July 2017

Table 5.7: Frequency Distribution Based on Smoking Ban member of mosque Antang 2017

Based on the table above (table 5.7) it can be known that out of 19 respondents, who did smoking ban as many as 14 people (73.7\%) and who did not do as many as 5 people (26.3\%).

4) Clean and healthy living behavior

Source : Primary Data, July 2017

\begin{tabular}{|l|l|l|l|}
\hline № & $\begin{array}{l}\text { Clean and Healthy Living } \\
\text { Behavior }\end{array}$ & Frequency & Percentage \% \\
\hline 1 & Good & 13 & 68,4 \\
\hline 2 & Less Good & 6 & 31,6 \\
\hline & Total & 19 & 100 \\
\hline
\end{tabular}

Table 5.8: Frequency Distribution Based on Clean and Healthy Living of Members of mosque Antang Year 2017 
Based on the table above (table 5.6) above, it can be known that out of 19 respondents, who had good clean and healthy living behaviors as many as 13 people $(68.4 \%)$ and the less good as many as 6 people $(31.6 \%)$.

\section{b. Bivariate Analysis}

To see the relationship between Islamic teachings about health and clean and healthy living behavior of the family order of members of the compound assembly of the mosque then used chi-square test using computer aids, with a level of meaning $\alpha=0.05$.

1) Relationship of Hand Washing Orders with Clean and Healthy Living Behavior

\begin{tabular}{|l|l|l|l|l|l|l|l|l|}
\hline \multirow{2}{*}{ №. } & \multirow{2}{*}{$\begin{array}{l}\text { HandWashing } \\
\text { Commands }\end{array}$} & \multicolumn{2}{l|}{$\begin{array}{l}\text { Life } \\
\text { Clean and Healthy }\end{array}$} & \multirow{2}{*}{$\begin{array}{l}\text { Q } \\
\text { Value }\end{array}$} \\
\cline { 3 - 9 } & & \multicolumn{2}{|l|}{ Good } & \multicolumn{2}{l}{$\begin{array}{l}\text { Less } \\
\text { Good }\end{array}$} & \\
\cline { 3 - 9 } & & $\mathrm{N}$ & $\%$ & $\mathrm{~N}$ & $\%$ & $\mathrm{~N}$ & $\%$ & \\
\hline 1. & Do & 12 & 63,2 & 0 & 0,0 & 12 & 63,2 & \\
\hline 2. & Not Doing & 1 & 5,3 & 6 & 31,6 & 7 & 36,8 & 0,000 \\
\hline & Total & 13 & 65,9 & 6 & 31,6 & 19 & 100 & \\
\hline
\end{tabular}

Primary: Data Source, July 2017

\section{Table 5.9: Relationship of Hand Washing Orders with Clean and Healthy Living Behavior of compound Assembly Members of mosque Antang 2017}

Based on the table above (table 5.9) it can be known that as many as 12 respondents $(63.2 \%)$ do hand washing orders with good clean and healthy living behavior, 0 respondents $(0.0 \%)$ doing hand washing orders with poor clean and healthy living behavior. While 1 respondent (5.3\%) do not do hand washing orders with good clean and healthy living behaviors and 6 respondents $(31.6 \%)$ do not carry out hand washing orders with poor clean and healthy living behaviors. Based on the table above it is also seen that with the chi square test used in this study to find out the relationship between hand washing orders and clean and healthy living behaviors obtained a significant figure of 0.000 which means there is a linear relationship between hand washing orders and clean and healthy living behaviors.

2) Relationship of defecation with clean living behavior and Healthy

\begin{tabular}{|c|c|c|c|c|c|c|c|c|}
\hline \multirow[t]{3}{*}{ №. } & \multirow[t]{3}{*}{ Defecation } & \multicolumn{4}{|c|}{$\begin{array}{l}\text { Life Behavior } \\
\text { Clean and Healthy }\end{array}$} & \multirow{2}{*}{\multicolumn{2}{|c|}{ Total }} & \multirow[t]{3}{*}{$\begin{array}{l}\text { Q } \\
\text { Value }\end{array}$} \\
\hline & & \multicolumn{2}{|c|}{ Good } & \multicolumn{2}{|c|}{$\begin{array}{l}\text { Less } \\
\text { Good }\end{array}$} & & & \\
\hline & & $\mathrm{N}$ & $\%$ & $\mathrm{~N}$ & $\%$ & $\mathrm{~N}$ & $\%$ & \\
\hline 1. & Do & 13 & 68,4 & 0 & 0,0 & 13 & 68,4 & \\
\hline 2. & Not Doing & 0 & 0,0 & 6 & 31,6 & 6 & 31,6 & 0,000 \\
\hline & Total & 13 & 68,4 & 6 & 31,6 & 19 & 100 & \\
\hline
\end{tabular}

Primary: Data Source, July 2017

Table 5.10: Defecation healthy style Relationship with Living Behavior and Healthy compound Assembly Members of mosgue Antang 2017

Based on the table above (table 5.10) it can be known that as many as 13 respondents $(68.4 \%)$ are doing defecation with good clean and healthy living behavior, 0 respondents $(0.0 \%)$ doing defecation with clean and healthy living behaviors that are not good. While 0 respondents $(0.0 \%)$ do not do defecation with good clean and healthy living behavior and 6 respondents $(31.6 \%)$ do not do defecation with clean and healthy behaviors that are not good. Based on the table above also seen that with the chi square test used in this study to find out the relationship between defecation waste and clean and healthy living behavior obtained a significant figure of 0.000 which means there is a linear relationship between defecation waste and clean and healthy living behavior.

3) The relationship of smoking ban with clean living behavior and Healthy.

\begin{tabular}{|l|l|l|l|l|l|l|l|l|}
\hline \multirow{2}{*}{ №. } & \multirow{2}{*}{ Smoking Ban } & \multicolumn{3}{|l|}{$\begin{array}{l}\text { Life } \\
\text { Clean and Healthy }\end{array}$} & \multirow{2}{*}{$\begin{array}{l}\text { Tetal } \\
\text { Value }\end{array}$} \\
\cline { 3 - 9 } & & Good & Less Good & & \\
\cline { 3 - 9 } & & $\mathrm{N}$ & $\%$ & $\mathrm{~N}$ & $\%$ & $\mathrm{~N}$ & $\%$ & \\
\hline 1. & Do & 13 & 68,4 & 1 & 5,3 & 14 & 73,7 & \\
\hline 2. & Not Doing & 0 & 0,0 & 5 & 26,3 & 5 & 26,3 & 0,001 \\
\hline & Total & 13 & 68,4 & 6 & 31,6 & 19 & 100 & \\
\hline
\end{tabular}

Primary:dataSource, July 2017

Table 5.11 The Relationship of Smoking Ban with Living Behavior Clean and Healthy compound Assembly Members of mosque Antang 2017

Based on the table above (table 5.11) it can be known that as many as 13 respondents $(68.4 \%)$ smoking ban with good clean and healthy living behavior, 1 respondent $(5.3 \%)$ is smoking with poor clean and healthy living behaviors. While 0 respondents $(0.0 \%)$ smoking ban with good clean and healthy living behavior and 5 respondents $(26.3 \%)$ do not do smoking ban with clean and healthy living behaviors that are not good. Based on the table above also seen that with the chi square test used in this study to find out the relationship between smoking ban with clean and healthy living behavior obtained a significant figure of 0.001 which 
means there is a linear relationship between defecation with clean and healthy living behavior.

\section{Discussion}

1. Based on the results of the study by comparing with the existing evidences and theories, it can be stated:

Relationship of Hand Washing Orders with Clean and Healthy Living Behavior. The univariate analysis showed that out of 19 respondents who were in the category of doing hand washing orders as many as 12 people $(63.2 \%)$ and who are in the category of not doing hand washing orders as many as 7 people (36.8\%). Researchers assume that the factor that causes respondents to perform hand washing orders is the faith factor.

Based on the word of god above, the Muslims at least wash their limbs 5 times a day that is during wudoo' for prayer. Washing your hands while wudoo' has health benefits. Washing the face and both hands to both elbows has a very large function in removing dust and various microbes, in addition to removing sweat from the surface of the skin. It also cleanses the skin of oily materials produced by the discharge of the skin glands. This by acclamation is a very relevant habitat for the life and breeding of germs. (Ahmad Ibnu salim baduwailan, 2012).

The respondents who were on the criteria did not do that amounted to 7 people $(36.8 \%)$, researchers claimed that the respondents had not fully carried out this order; this is evidenced by the observations made. Where they are still forget to wash their hands before eating.

Based on statistical tests with chi-square method with a meaning level of $\alpha=0.05$, obtained the value of $p=0,000<\alpha=0.05$ this indicates that Ho was rejected and $\mathrm{Ha}$ accepted thus "there is a relationship between hand washing orders and clean and healthy living behavior".

2. Defecation healthy style Relationship with Clean and Healthy Living Behavior

The univariate analysis showed that out of 19 respondents who were in the category of doing defecation healthy style as many as 13 people $(68.4 \%)$ and who are in the category of not conducted defecation healthy style waste as many as 6 people (31.6\%).

The researchers assumed that the respondents performed a banishment because of the faith factor in which the defecation healthy style had been regulated in the religion of Islam long before it was determined by the health service of the Republic of Indonesia listed in the program of clean and healthy living behavior as well as the command to wash hands. Carrying out adab defecation inside and outside the household will form a clean and healthy environment.

The respondents who were on the criteria did not do that amounted to 6 people $(31.6 \%)$. researchers claimed that respondents have not fully carried out this order, where respondents have not met some criteria set by researchers, such as some respondents who have not been able to carry out custom of defecation while outdoors or are not finding latrines or the like.

Based on statistical tests with chi-square method with a value of $\alpha=0.05$, obtained the value of $\mathrm{p}=0,000<\alpha=0.05$ this indicates that Ho was rejected and $\mathrm{Ha}$ accepted thus "there is a relationship between defecation custom with clean and healthy living behavior".

3. Smoking Prohibition Relationship with Clean and Healthy Living Behavior

Univariate analysis showed that out of 19 respondents who were in the category of smoking ban as many as 14 people (73.7\%) and who are in the category of not doing custom defecation deed as many as 5 people $(26.3 \%)$.
Researchers assume that respondents do not smoke in the sense of not smoking, the same as the previous independent variable, namely because of the faith factor, where smoking is one of the things that are harmful to the body and all that is dangerous is prohibited in religion to be consumed or such.

The verse above is a very strong foundation to leave everything that is harmful to the body such as cigarettes. The cultural center in Halab city once held a seminar on health. In the seminar delivered scientific speeches by doctors who have similar views that cigarettes are harmful to health. Cigarettes are important factors that cause the onset of throat cancer, lung cancer, heart attack, tuberculosis, gastric injury and others. Cigarettes contain a variety of toxins, while the most dangerous toxins are nicotine, tar and various other damaging toxins. (Shaykh Muhammad Jamil Zainu, 2003)

Dr. Kan'an Al Jabi, professor of the Faculty of Medicine, in a scientific lecture openly stated "I have been dealing with cankey disease for twentyfive years. All patients with throat cancer can be sure to smokers....". Another doctor, doctor Akhsa-I, an internal medicine specialist, in his talk asserted that smoking ten cigarettes a day is very dangerous for health. Then he said, "Ninety percent of cancer patients are smokers". (Shaykh Muhammad Jamil Zainu, 2003).

Based on some of the facts revealed by some of the specialists above, it is really a proof that cigarettes are one of the objects that are harmful to the body that is certainly prohibited in Islam to be consumed. Indeed faith and believe of God is an obligation that has benefits in this world and the Hereafter.

\section{References}

1. Achar, H.A.K. (2013). Teori dan Praktik Asuhan Keperawatan Komunitas.

2. Ahmad, Y.A . Ensiklopedia Kemukjizatan Ilmiah dalam AlQuran dan Sunah. PT

3. Kharisma Ilmu

4. Askary. (2012). Obat Segala Penyakit

5. Askary .(2013). Keutamaan Menuntut IlmuAgama.

6. Admin. (2012). Adab makan dan minumh

7. Admin. (2015). Defenisi, Tingkatan Diin, Islam, Iman.

8. Admin. (2009). Tata Cara Pengobatan Rasulullah Shallahu 'Alaihi Wa Sallam.

9. Admin. (2008). Tips nabawi ketika buang air.

10. Bahrain, (2012). Asi Eksklusif selama Dua Tahun dalam Ajaran Islam.

11. Baduwailan, A.B.S. (2012). Terapi Mengobati Penyakit dengan Shalat, Manfaat Kesehatan dan Kejiwaan di balik Wudhu dan Shalat, Jakarta : Pustaka at-Tazkia

12. Dinas Kesehatan Provinsi Sulawesi Selatan. (2013). Profil Kesehatan Provinsi Sulawesi Selatan 2014.

13. Dinas Kesehatan Kota Makassar. (2013). Profil Kesehatan Kota Makassar.

14. Gaib. (2011). Uji Kai Kuadrat (Chi Square Test).

15. Jabir, A.B.A. (2012). Minhajul Muslim, Pedoman Hidup Ideal Seorang Muslim, Surakarta : Insan Kamil

16. Maryunani, A., \& TIM. (2013). Perilaku hidup bersih dan sehat, Jakata : Trans Info Media Jakarta

17. Nursalam. (2011). Konsep dan Penerapan Methodology Penelitian Ilmu Keperawatan, Pedoman Skripsi, Tesis, dan Instrumen Penelitian Keperawatan. Salemba Medika

18. Pratiwi , A. (2011). Buku Ajar Keperawatan Transkultural, Gosyen Publishing

19. Proverwati, A., \& Rahmawati, E. (2012). Perilaku Hidup Bersih dan sehat, Nuha Medika 
20. Pieter Zan Herri., \& Lubis Lumongga Namora. (2010). Pengantar Psikologi dalam Keperawatan. Kencana Prenada Media Group

21. Prasetyawati, E.A. (2011). Ilmu Kesehatan Masyarakat untuk Kebidanan Holistik. Nuha Media

22. Putra .(2014). Makalah Fungsi Majelis Taklim dalam Penyadaran Agama.
23. Syaikh Muhammad Bin Abdul Wahhab Tiga Landasan Utama. Riyadh : Dar Al-Gasem.

24. Saam, Z.M.S., \& Sriwahyuni. (2012). Psikologi Keperawatan. Rajawali Pers

25. Zainu, M.J. (2003). No Smoking Tidak Merokok Karena Allah, Jogjakarta :Media Hidayah
This work is licensed under Creative Commons Attribution 4.0 License

To Submit Your Article Click Here: Submit Manuscript

DOI: $10.31579 / 2690-8808 / 091$
Ready to submit your research? Choose Auctores and benefit from:

$>$ fast, convenient online submission

$>$ rigorous peer review by experienced research in your field

$>$ rapid publication on acceptance

$>$ authors retain copyrights

$>$ unique DOI for all articles

$>$ immediate, unrestricted online access

At Auctores, research is always in progress.

Learn more https://auctoresonline.org/journals/journal-of-clinical-casereports-and-studies 